OPEN ACCESS

Edited by:

Mark S. Cragg,

University of Southampton,

United Kingdom

Reviewed by:

Adam D. Hoppe,

South Dakota State University,

United States

Ricciarda Galandrini

Sapienza University of Rome, Italy

*Correspondence:

George Georgiou

gg@che.utexas.edu

tPresent Address:

Tae Hyun Kang,

Biopharmaceutical Research Center

CJ Healthcare R\&D Center, CJ

HealthCare, Icheon, South Korea

¥These authors have contributed equally to this work

§Co-first author

Specialty section:

This article was submitted to

Molecular Innate Immunity,

a section of the journal

Frontiers in Immunology

Received: 03 December 2018 Accepted: 04 March 2019

Published: 27 March 2019

Citation:

Kang TH, Lee C-H, Delidakis G, Jung J, Richard-Le Goff O, Lee J, Kim JE,

Charab W, Bruhns $P$ and Georgiou $G$

(2019) An Engineered Human Fc

variant With Exquisite Selectivity for

FC $\gamma$ RIllav158 Reveals That Ligation of

FcyRllia Mediates Potent Antibody

Dependent Cellular Phagocytosis With GM-CSF-Differentiated Macrophages.

Front. Immunol. 10:562.

doi: 10.3389/fimmu.2019.00562

\section{An Engineered Human Fc variant With Exquisite Selectivity for Fc $\gamma$ RIIlav158 Reveals That Ligation of FcyRIIla Mediates Potent Antibody Dependent Cellular Phagocytosis With GM-CSF-Differentiated Macrophages}

Tae Hyun Kang ${ }^{1 \neq \neq}$, Chang-Han Lee ${ }^{1 \neq \$}$, George Delidakis ${ }^{1}$, Jiwon Jung ${ }^{2}$, Odile Richard-Le Goff ${ }^{3}$, Jiwon Lee ${ }^{1}$, Jin Eyun Kim ${ }^{2}$, Wissam Charab ${ }^{1}$, Pierre Bruhns ${ }^{3,4}$ and George Georgiou $1,2,5,6 *$

${ }^{1}$ Department of Chemical Engineering, University of Texas at Austin, Austin, TX, United States, ${ }^{2}$ Department of Biomedical Engineering, University of Texas at Austin, Austin, TX, United States, ${ }^{3}$ Unit of Antibodies in Therapy and Pathology, Department of Immunology, Institut Pasteur, Paris, France, ${ }^{4}$ INSERM, U1222, Paris, France, ${ }^{5}$ Center for Systems and Synthetic Biology, University of Texas at Austin, Austin, TX, United States, ${ }^{6}$ Department of Molecular Biosciences, University of Texas at Austin, Austin, TX, United States

IgG antibodies mediate the clearance of target cells via the engagement of Fc gamma receptors (Fc $\gamma R s$ ) on effector cells by eliciting antibody-dependent cellular cytotoxicity and phagocytosis (ADCC and ADCP, respectively). Because (i) the IgG Fc domain binds to multiple Fc $\gamma$ Rs with varying affinities; (ii) even low Fc:Fc $\gamma$ Rs affinity interactions can play a significant role when antibodies are engaged in high avidity immune complexes and (iii) most effector cells express multiple FcyRs, the clearance mechanisms that can be mediated by individual FcyR are not well-understood. Human FcyRIIla (hFcyRIlla; CD16a), which exists as two polymorphic variants at position 158, hFc $\gamma R$ Rlllav158 and $\mathrm{hFC} \gamma \mathrm{RIIll} \mathrm{a}_{\mathrm{F} 158}$, is widely considered to only trigger ADCC, especially with natural killer (NK) cells as effectors. To evaluate the role of $\mathrm{hFc} \gamma \mathrm{R}$ Illa ligation in myeloid-derived effector cells, and in particular on macrophages and monocytes which express multiple FcyRs, we engineered an aglycosylated engineered human $\mathrm{Fc}_{\mathrm{c}}(\mathrm{hFc})$ variant, Fc3aV, which binds exclusively to hFcyRIllav158. Antibodies formatted with the Fc3aV variant bind to the hFcyRIllav158 allotype with a somewhat lower $K_{D}$ than their wild type IgG1 counterparts, but not to any other hFc $\gamma R$. The exceptional selectivity for hFc $\gamma R$ Illav158 was demonstrated by SPR using increased avidity, dimerized GST-fused versions of the ectodomains of hFcyRs and from the absence of binding of large immune complex (IC) to $\mathrm{CHO}$ cells expressing each of the $\mathrm{hFc} \gamma \mathrm{Rs}$, including notably, the FcyRllla $\mathrm{F}_{\mathrm{F} 158}$ variant or the highly homologous Fc $\gamma$ RIlllb. We show that even though monocyte-derived GM-CSF differentiated macrophages express $\mathrm{hFc} \gamma \mathrm{R}$ Illa at substantially lower levels than the other two major activating receptors, namely $\mathrm{hFc} \gamma \mathrm{Rl}$ or hFc $\gamma \mathrm{R}$ Illa, Fc3aV-formatted Rituximab and Herceptin perform ADCP toward CD20- and Her2-expressing 
cancer cells, respectively, at a level comparable to that of the respective wild-type antibodies. We further show that $\mathrm{hFc} \gamma \mathrm{R}$ Illa activation plays a significant role on ADCC by human peripheral monocytes. Our data highlight the utility of Fc3aV and other similarly engineered exquisitely selective, aglycosylated Fc variants toward other hFc $\gamma$ Rs as tools for the detailed molecular understanding of $h F c \gamma R$ biology.

\section{Keywords: Fc engineering, ADCP, FcgR, macrophage, monocyte}

\section{INTRODUCTION}

Antibodies regulate a variety of immune responses by engaging $\mathrm{Fc} \gamma$ receptors ( $\mathrm{Fc} \gamma \mathrm{Rs}$ ) expressed on various leukocytes such as macrophages, granulocytes, dendritic cells (DCs), natural killer (NK) cells, and B cells. Immune complexes (ICs) formed by antibodies binding to multivalent antigens such as viruses and antibody-opsonized cancer or infected cells, induce activating Fc $\gamma$ R-mediated immunoreceptor tyrosine-based activation motif (ITAM) signaling in effector cells, thereby inducing antibodydependent cellular cytotoxicity and phagocytosis (ADCC/P) $(1,2)$. The activation of immune cells upon binding to ICs is regulated by the immunoreceptor tyrosine-based inhibitory motif (ITIM) signaling of the inhibitory Fc $\gamma$ RIIb $(3,4)$. The ensuing signaling processes and immunological mechanisms triggered by IC binding depend on the expression level of Fc $\gamma$ Rs on various immune cell subsets and on the binding affinity of the Fc domain to the different Fc $\gamma$ Rs $(2,5)$. The composition of the single glycan at N297 of the human IgG1 Fc domain is known to both affect human $\mathrm{Fc} \gamma \mathrm{R}(\mathrm{hFc} \gamma \mathrm{R})$ receptor affinity and, in some instances, to trigger additional signaling pathways via binding to the lectin-like type II receptors (6).

Human FcyRIIIa (hFcyRIIIa; CD16a) has been reported to be the most potent receptor for mediating $\operatorname{ADCC}(7,8)$. NK cells which are considered to be the most important contributor to ADCC with peripheral blood mononuclear cells (PBMCs) as effector cells, express only hFc $\gamma$ RIIIa (2). hFc $\gamma$ RIIIa is also expressed in intermediate $\left(\mathrm{CD} 14^{\mathrm{hi}} / \mathrm{CD} 16^{+}\right)$ and non-classical (CD14 $\left.4^{\mathrm{dim}} / \mathrm{CD} 16^{\mathrm{hi}}\right)$ blood monocytes which are capable of inducing ADCC primarily via $\mathrm{TNF} \alpha$ secretion $(9,10)$. Among the four human IgG subclasses, IgG1 and IgG3 have the higher affinity for hFc $\gamma$ RIIIa resulting in more potent ADCC in vitro (5, 11-13). A single nucleotide polymorphism of hFc $\gamma$ RIIIa at residue 158 which can be either Val and Phe is prevalent in humans. Earlier studies revealed that lymphoma patients expressing the higher affinity hFc $\gamma$ RIIIav158 variant show improved clinical outcomes when treated with anti-CD20 (rituximab) and anti-Her2 (trastuzumab) compared to patients homozygous for the lower affinity, hFc $\gamma$ RIIIa 158 (14-17). The finding that higher affinity to hFc $\gamma$ RIIIa may lead to greater therapeutic potency stimulated extensive efforts to engineer $\mathrm{hFc}$ domains with improved binding $\mathrm{hFc} \gamma \mathrm{RIIIa}$ via either site-directed mutagenesis or glycoengineering, the latter accomplished primarily by completely abolishing or by reducing fucosylation (18-21). hFc defucosylated antibodies have up to 50 -fold enhanced affinity to hFc $\gamma$ RIIIa and three defucosylated antibodies, anti-CCR4 mogamulizumab, anti-IL5Ra benralizumab, and anti-CD20 obinutuzumab, have been evaluated for multiple therapeutic indications and approved for clinical use $(21,22)$.

Earlier reports had suggested that the improved therapeutic efficacy of antibodies having increased hFc $\gamma$ RIIIa affinity is due to more effective priming and activation of NK cells $(8,23$, 24). However, in more recent studies it was observed that the depletion of macrophages, which are the predominant mediators of ADCP in tissues (25), abrogated the therapeutic efficacy of anti-CD20, anti-CD30, or anti-CD40 antibodies in mouse models whereas removal of NK cells or neutrophils did not significantly affect therapeutic efficacy (26-29). These results underline the critical role of tissue-resident macrophages and ADCP in antitumor antibody immunotherapy. ADCP is mainly attributed to signaling via hFc $\gamma$ RIIa, which is expressed at high levels on macrophages (30-32). Indeed, hFc-engineered antibodies with increased hFc $\gamma$ RIIa binding confer more potent ADCP $(29,31)$. Conversely, glycoengineered antibodies do not display higher affinity toward hFc $\gamma$ RIIa (33), but have been shown to increase macrophage phagocytic activity (34), potentially through hFc $\gamma$ RIIIa signaling.

hFc $\gamma$ RIIIa is expressed at much lower levels than hFc $\gamma$ RIIa in human in vitro monocyte-derived GM-CSF differentiated macrophages (gmM $\phi)(30-32,35)$. Thus, the importance of $\mathrm{hFc} \gamma \mathrm{RIII}$ a engagement in mediating ADCP is an overlooked issue (36-38). Delineating the role of a particular $h F c \gamma R$ by blocking other receptors with antibodies can be problematic for two reasons: First, in vitro the cross-linking of the targeted $\mathrm{hFc} \gamma \mathrm{R}$ by blocking antibodies can alter the distribution of receptors on the membrane and also the blocking antibodies may impede the accessibility of other Fc $\gamma \mathrm{R}$ impacting the binding of immune complexes to other hFc $\gamma$ Rs. Secondly, the co-administration of $\mathrm{hFc} \gamma \mathrm{R}$ blocking antibodies can complicate the design and interpretation of in vivo experiments. To circumvent these limitations our lab has been developing engineered Fc domains that have absolute selectivity for only one $\mathrm{Fc}$ binding protein $(39,40)$. The binding of IgG antibodies to $h F c \gamma R s$ or to the $\mathrm{Clq}$ component of the complement system is critically dependent on N-linked glycan at residue N297 of the Fc (41). Loss of the glycan increases the conformational flexibility of the $\mathrm{CH} 2$ domain resulting in very significant, albeit not complete loss of $\mathrm{hFc} \gamma \mathrm{R}$ and $\mathrm{C} 1 \mathrm{q}$ binding and in drastically diminished effector functions $(39,42-44)$. Previously, our lab has developed an Fc variant, Fc5, that binds only to the high affinity hFc $\gamma \mathrm{RI}$ and not to any other human Fc $\gamma$ R. We further demonstrated that antibodies formatted with the Fc5 domain potentiate effective 
tumor cell death by monocyte-derived DCs via the ligation of Fc $\gamma$ RI (39). In this work, we report on the engineering of an aglycosylated $\mathrm{hFc}$ domain, $\mathrm{Fc} 3 \mathrm{aV}$, that has essentially absolute specificity for the $h F c \gamma$ RIIIav158 allotype. Using antibodies equipped with the $\mathrm{Fc} 3 \mathrm{aV}$ variant, we showed that exclusive engagement of hFc $\gamma$ RIIIa results in potent ADCP with gmM $\phi$ and also established the role of this receptor on ADCC with monocytes as effectors.

\section{MATERIALS AND METHODS}

\section{Cells And Reagents}

Burkitt's lymphoma Raji cells (ATCC ${ }^{\circledR}$ CCL-86 ${ }^{\mathrm{TM}}$ ) and SK-BR3 breast tumor cell lines (ATCC ${ }^{\circledR}$ HTB-30 ${ }^{\mathrm{TM}}$ ) were obtained from American Type Culture Collection. Raji cells were cultured in complete RPMI with $10 \%$ fetal bovine serum (FBS) and SK-BR-3 cells were cultured in complete DMEM with $10 \%$ FBS. The collections of $\mathrm{CHO}$ cells expressing FLAG-tagged $\mathrm{hFc} \gamma \mathrm{Rs}$ were described previously (14, 40, 45).

Human PBMCs and neutrophils were purified from anonymous healthy volunteers using Histopaque density gradient centrifugation (Sigma-Aldrich). Neutrophils were activated with $50 \mathrm{ng} / \mathrm{mL}$ hIFN $\gamma$ for $24 \mathrm{~h}$. NK cells were isolated by negative immunodensity isolation using the RosetteSep Human NK Cell Enrichment Cocktail (StemCell Technologies). Human GM-CSF differentiated macrophage cells were differentiated from $\mathrm{CD}_{14}{ }^{+}$monocytes with $50 \mathrm{ng} / \mathrm{mL}$ GM-CSF (BioLegend ${ }^{\circledR}$ ) for 7 days. Ectodomains of hFc $\gamma$ RI, hFc $\gamma$ RIIa, hFc $\gamma$ RIIb, and hFc $\gamma$ RIIIa, were produced in Expi293 cells (Invitrogen). All primers were synthesized by Integrated DNA Technologies.

\section{Library Screening for $\mathrm{hFc} \gamma \mathrm{R}$ Illa-Selective hFc Variant}

As reported previously (40), E. coli cells expressing an IgGlibrary (E-library) were cultured overnight at $37^{\circ} \mathrm{C}$ with 250 rpm shaking in Terrific Broth media (TB, Difco ${ }^{\mathrm{TM}}$ ) with $2 \%$ $(\mathrm{w} / \mathrm{v})$ glucose, antibiotics $(35 \mu \mathrm{g} / \mathrm{ml}$ of chloramphenicol and $50 \mu \mathrm{g} / \mathrm{ml}$ kanamycin). Following overnight growth, cells were diluted 1:100 in fresh TB medium and were induced with $1 \mathrm{mM}$ of isopropyl-1-thio- $\beta$-D-galactopyranoside (IPTG) and $0.2 \% \mathrm{~L}$ arabinose. Following incubation at $25^{\circ} \mathrm{C}$ for $20 \mathrm{~h}$, the library cells were spheroplasted. as described previously (40). Spheroplasts were labeled with $10 \mathrm{nM}$ dimeric $\mathrm{hFc} \gamma \mathrm{RIIIa} / 58^{-G S T-r P E}$ and $100 \mathrm{nM}$ of unconjugated dimeric hFc $\gamma$ RIIb-GST and sorted using a FACSAria $^{\mathrm{TM}}$ flow cytometer. FACS data were analyzed with FACSDiva software. For FACS screening, clones corresponding to the top $1 \%$ fluorescent events were isolated. Sorted spheroplasts were resorted immediately after initial sorting. The hFc mutant genes in the resorted spheroplasts rescued by PCR were cloned into SfiI digested pPelB-AglycoT(H)-FLAG vector, and transformed into electro-competent E. coli Jude-1 harboring pBAD-AglycoT(L)-His. The resulting transformants were subjected to a next round of sorting and resorting.

\section{Expression and Purification of IgG Antibodies and $\mathrm{hFc} \gamma \mathrm{Rs}$}

IgGl antibodies and $\mathrm{hFc} \gamma \mathrm{Rs}$ proteins were produced by transient transfection of Expi293F cells (Thermo Fisher Scientific) using the pcDNA3.4 vector (Thermo Fisher Scientific). Antibodies were purified by Protein A high capacity agarose resin (Thermo Fisher Scientific) affinity chromatography. $25 \times$ PBS was added to filtered supernatants to a $1 \times$ concentration, and the mixture was passed twice over the column. The column was washed with $100 \mathrm{ml}$ of $1 \mathrm{x}$ PBS to remove nonspecifically bound proteins. Three milliliters of $100 \mathrm{mM}$ glycine- $\mathrm{HCl}(\mathrm{pH} 2.7)$ was added to elute the bound proteins, and the elution was immediately neutralized with $1 \mathrm{ml}$ of $1 \mathrm{M}$ Tris ( $\mathrm{pH}$ 8.0). Samples were bufferexchanged into pH7.4 PBS using Amicon Ultra-4 (Millipore) spin columns with a $10 \mathrm{kDa}$ cutoff. The purity of purified samples was assessed by 4-20\% gradient SDS-PAGE gel (NuSep).

\section{ELISA and SPR Analysis}

Fifty microliters of $4 \mu \mathrm{g} / \mathrm{ml}$ of Trastuzumab IgG1 or its hFc variants were diluted in pH7.4 phosphate buffered saline (PBS) buffer and used to coat 96 well polystyrene ELISA plate (Corning) overnight at $4^{\circ} \mathrm{C}$. After blocking with $1 \mathrm{x}$ PBS ( $\mathrm{pH} 7.4$ ) containing $0.5 \%$ BSA for $2 \mathrm{~h}$ at room temperature, the plate was washed 4 times with PBS containing 0.05\% Tween20 (PBST), and incubated with serially diluted dimeric GST-tagged low affinity $\mathrm{hFc} \gamma \mathrm{Rs}$ and monomeric his-tagged high affinity hFc $\gamma \mathrm{RI}$ at room temperature for $1 \mathrm{~h}$. After washing 4 times with the PBST buffer, either 1:10,000 diluted $\alpha$-GST (GE Healthcare) or $\alpha$-His antibody HRP conjugate were added. After washing three times with PBST, $50 \mu \mathrm{L}$ TMB substrate was added per well (Thermo Scientific), 50 $\mu \mathrm{L}$ of $1 \mathrm{M} \mathrm{H}_{2} \mathrm{SO}_{4}$ was added to neutralize, and the absorbance at $450 \mathrm{~nm}$ was recorded.

For SPR analysis, Trastuzumab IgG1 or its variants were individually immobilized on CM5 sensor chips by amine coupling, as recommended by the manufacturer (GE Healthcare). Binding experiments were performed in HBS-EP buffer $(10 \mathrm{mM}$ HEPES pH 7.4, $150 \mathrm{mM} \mathrm{NaCl}, 3.4 \mathrm{mM}$ EDTA, and $0.005 \%$ P20 surfactant). Serially diluted dimeric GST-tagged low affinity $\mathrm{hFc} \gamma \mathrm{Rs}$ or monomeric his-tagged high affinity $\mathrm{hFc} \gamma \mathrm{RI}$ were injected at a flow rate of $30 \mu \mathrm{l} / \mathrm{min}$ for $60 \mathrm{~s}$ with a dissociation time of $5 \mathrm{~min}$. The chip was regenerated after each run by sequential injection of $50 \mathrm{mM}$ glycine, $\mathrm{pH}$ 4.0, $50 \mathrm{mM}$ glycine, $\mathrm{pH}$ 9.5, and $3 \mathrm{M} \mathrm{NaCl}$ for $1 \mathrm{~min}$ each. For each run, a bovine serum albumin (BSA)-coupled surface was used as reference channel. Equilibrium dissociation constants $\left(\mathrm{K}_{\mathrm{D}}\right)$ for monovalent receptor binding were determined by fitting 1:1 Langmuir model to the data using BIAevaluation 3.2 software (GE Healthcare) and the $\mathrm{K}_{\mathrm{D}} s$ were averaged from three independent experiments $(n=3$ for hFc $\gamma$ RIIa and hFc $\gamma$ RIIIa, $n=2$ for hFc $\gamma$ RI and hFc $\gamma$ RIIb). The resulting sensorgrams were fit with a 1:1 Langmuir isotherm model or equilibrium binding model for monomeric $h F c \gamma$ Rs using Biaevaluation 3.0 software.

\section{Antibody Binding Activities to Cancer Cells}

Raji cells or SK-BR-3 cells $\left(10^{5}\right.$ cells) were incubated with various concentration of antibody variants for $30 \mathrm{~min}$ at 
$4^{\circ} \mathrm{C}$ and washed with $3 \%$ BSA in PBS. Raji- or SK-BR3bound antibody levels were detected by FITC-conjugated, $\mathrm{F}\left(\mathrm{ab}^{\prime}\right)_{2}$ Fragment, goat Anti-Human IgG Fc (Jackson ImmunoResearch Laboratories).

\section{Immune Complex Binding Activities to $\mathrm{hFc} \gamma \mathrm{Rs}$}

$\mathrm{CHO}$ cells expressing FLAG-tagged hFc $\gamma$ Rs were described previously $(14,40,45)$. ICs were also generated by mixing $10 \mu \mathrm{g} / \mathrm{ml}$ of Trastuzumab or Trastuzumab-Fc3aV and $5 \mu \mathrm{g} / \mathrm{ml}$ of PE-conjugated $\mathrm{F}\left(\mathrm{ab}^{\prime}\right)_{2}$ goat anti-human IgG $\mathrm{F}\left(\mathrm{ab}^{\prime}\right)_{2}$ (Jackson ImmunoResearch Laboratories) for $30 \mathrm{~min}$ at $37^{\circ} \mathrm{C}(14,40,45)$. $\mathrm{CHO}$ cells expressing $\mathrm{hFc} \gamma \mathrm{Rs}$ were incubated with ICs for $1 \mathrm{~h}$ on ice and cell-bound ICs were detected by flow cytometry on a MACSQuant (Miltenyi Biotech). Data were analyzed with Flow Cytometry Analysis Software (FlowJo). The IC-binding activities to NK cells or neutrophils were also assayed and measured using same method, but using a FACS Calibur (BD Biosciences).

\section{In vitro Cell-Based Assays FCGR3A SNP Genotyping}

As previously described $(46,47)$, FCGR3A genes were specifically amplified using the following primers, $5^{\prime}$-TCC AAA AGC CAC ACT CAA AGA CAG CGC- $3^{\prime}$ and $5^{\prime}$-GAT GGT GAT GTT CAC AGT CTC T- $3^{\prime}$ and the sequence of amplified FCGR3A was analyzed. FCGR3A SNP was also confirmed by nested PCR using following primer sets; $5^{\prime}$-TCC AAA AGC CAC ACT CAA AGA CAG CGC- $3^{\prime}$ and $5^{\prime}$-CTC TGA AGA CAC ATT TTT ACT CCC AAA-3' for FCGR3A F158, and 5'-TCC AAA AGC CAC ACT CAA AGA CAG CGC- $3^{\prime}$ and CTC TGA AGA CAC ATT TTT ACT CCC AAC for FCGR3A V158.

\section{ADCC Assays}

SK-BR-3 or Raji cells were cultured in complete DMEM or RPMI medium as above and collected by centrifugation at 300x g for $5 \mathrm{~min}$. Cells were washed in PBS and labeled with $4 \mu \mathrm{M}$ Calcein $\mathrm{AM}$ (Invitrogen) in $\mathrm{PBS}$ at $37^{\circ} \mathrm{C}$ with $5 \% \mathrm{CO}_{2}$ for $30 \mathrm{~min}$. Calcein-loaded cancer cells were washed twice, resuspended in RPMI medium, and seeded into a 96-well plate at 10,000 cells/well with various concentrations of IgG variants. As previously described $(40,48)$, PBMCs and PMNs were isolated from healthy anonymous donors using Histopaque (SigmaAldrich). $\mathrm{CD}_{1}{ }^{+}$monocytes were isolated from PBMCs by magnetic bead separation (EasySep by STEMCELL Inc.) (40). Effector cells were added into a 96-well plate at 100,000 cells/well and the plates were incubated at $37^{\circ} \mathrm{C}$ with $5 \% \mathrm{CO}_{2}$ for $4 \mathrm{~h}$. Released calcein AM was detected at excitation and emission wavelengths of 485 and $535 \mathrm{~nm}$, respectively. The percent of tumor cell lysis was calculated according to the following formula; $100 \times(\mathrm{E}-\mathrm{S}) /(\mathrm{M}-\mathrm{S})$, where $\mathrm{E}$ is the fluorescence of experimental well, $\mathrm{S}$ is that in the absence of antibody (tumor cells were incubated with medium and complement alone), and $\mathrm{M}$ is that of tumor cells with lysis buffer (Triton X-100 at 2\% v/v, SDS $1 \% \mathrm{w} / \mathrm{v}, 100 \mathrm{mM} \mathrm{NaCl}$, and $1 \mathrm{mM}$ EDTA).

\section{ADCP Assays}

Purified monocytes were differentiated into GM-CSF differentiated macrophages $(\mathrm{gmM} \phi)$ by culture for 7 days in RPMI medium containing $10 \% \mathrm{FBS}$ and $50 \mathrm{ng} / \mathrm{ml}$ GMCSF. Harvested gmM $\phi$ by trypsinization were seeded into 96-well plate at $10^{5}$ cells/well and then cultured in RPMI medium containing 10\% FBS overnight. SK-BR-3 or Raji cells, were labeled with PKH67 (Sigma-Adrich) according to the manufacturer's instructions and opsonized by serially diluted IgG variants. IgG-opsonized and $\mathrm{PKH}-67$-labeled cancer cells were added into gmM $\phi$-attached 96-well plate at $10^{4}$ cells/well. After $2 \mathrm{~h}$ at $37^{\circ} \mathrm{C}$ with $5 \% \mathrm{CO}_{2}$, gmM $\phi$ cells were detached from the plate by Trypsin-EDTA treatment for $20 \mathrm{~min}$. gmM $\phi$ were stained with anti-CD45-APC (BD bioscience) for ADCP assay with SK-BR-3 cells on ice for $15 \mathrm{~min}$. For ADCP assay with Raji cells, gmM $\phi$ were stained with anti-CD14-APC and anti-CD11b-APC (Biolegend) on ice for $15 \mathrm{~min}$. Phagocytosis was evaluated by FACSAria $^{\mathrm{TM}}$ (BD Bioscience), and reported as the fraction of double positive cells over the total number of tumor cells in the sample.

Blockade assays for $\mathrm{hFc} \gamma \mathrm{RIII}$ a were performed as follows; gmM $\phi$ were pre-incubated with $10 \mu \mathrm{g} / \mathrm{ml}$ of anti-CD16 mAb 3G8 $\mathrm{F}\left(\mathrm{ab}^{\prime}\right)_{2}$ (Ancell) (49-51) was pre-incubated with gmM $\phi$ for $10 \mathrm{~min}$. IgG-opsonized and PKH-67-labeled cancer cells were then incubated with anti-CD16 mAb $3 \mathrm{G} 8 \mathrm{~F}\left(\mathrm{ab}^{\prime}\right)_{2}$-coated gmM $\phi$ in RPMI1640 medium without serum. After $2 \mathrm{~h}$ at $37^{\circ} \mathrm{C}$, the fraction of phagocytosed tumor cells was detected as described above. For all assays, an E:T ratio of 10:1 was used.

Fluorescent images of macrophages phagocytozing cancer cells were obtained by confocal microscopy using calcein AMloaded Raji cells or SK-BR-3 cells opsonized with $20 \mu \mathrm{g} / \mathrm{ml}$ of antibodies and $\operatorname{gmM} \phi$ at $37^{\circ} \mathrm{C}$ for $1 \mathrm{~h}$. Approximately 1 $\times 10^{5}$ labeled cancer cells and $1 \times 10^{5}$ macrophages were co-incubated in $1 \mathrm{ml}$ of RPMI medium. Subsequently, the coincubated cells were labeled as described above. Phagocytosis was visualized by confocal microscopy using Zeiss LSM 710/Elyra S.1.

\section{RESULTS}

\section{Directed Evolution for $\mathrm{hFc} \gamma \mathrm{RIIla}$-Specific Binding hFc Variant}

Aglycosylated $\mathrm{hFc}$ domains specific for $\mathrm{hFc} \gamma \mathrm{RIIIa}$ were engineered via the screening of combinatorial libraries expressed in E. coli using a well-established full-length IgG-display system in bacteria $(36,40)$. Briefly, the heavy chain and light chains of IgG (having Trastuzumab Fab arms) were separately expressed by fusing pelB and NlpA, respectively resulting in tethering of IgG on the periplasmic side of the inner membrane. In order to isolate $h F c \gamma$ RIIIA-selective aglycosylated $h F c$ variants, the IgG $\mathrm{hFc}$ domain was mutagenized by error-prone PCR and a library of $>10^{9}$ E. coli transformants was generated. The bacterial cells (40) were spheroplasted and the library was screened with $10 \mathrm{nM}$ of dimeric $\mathrm{hFc} \gamma \mathrm{RIIIA}_{\mathrm{V} 158}$-GST, conjugated with $\mathrm{rPE}$ in the presence of $100 \mathrm{nM}$ of unconjugated $\mathrm{hFc} \gamma \mathrm{RIIB}-\mathrm{GST}$ as a 

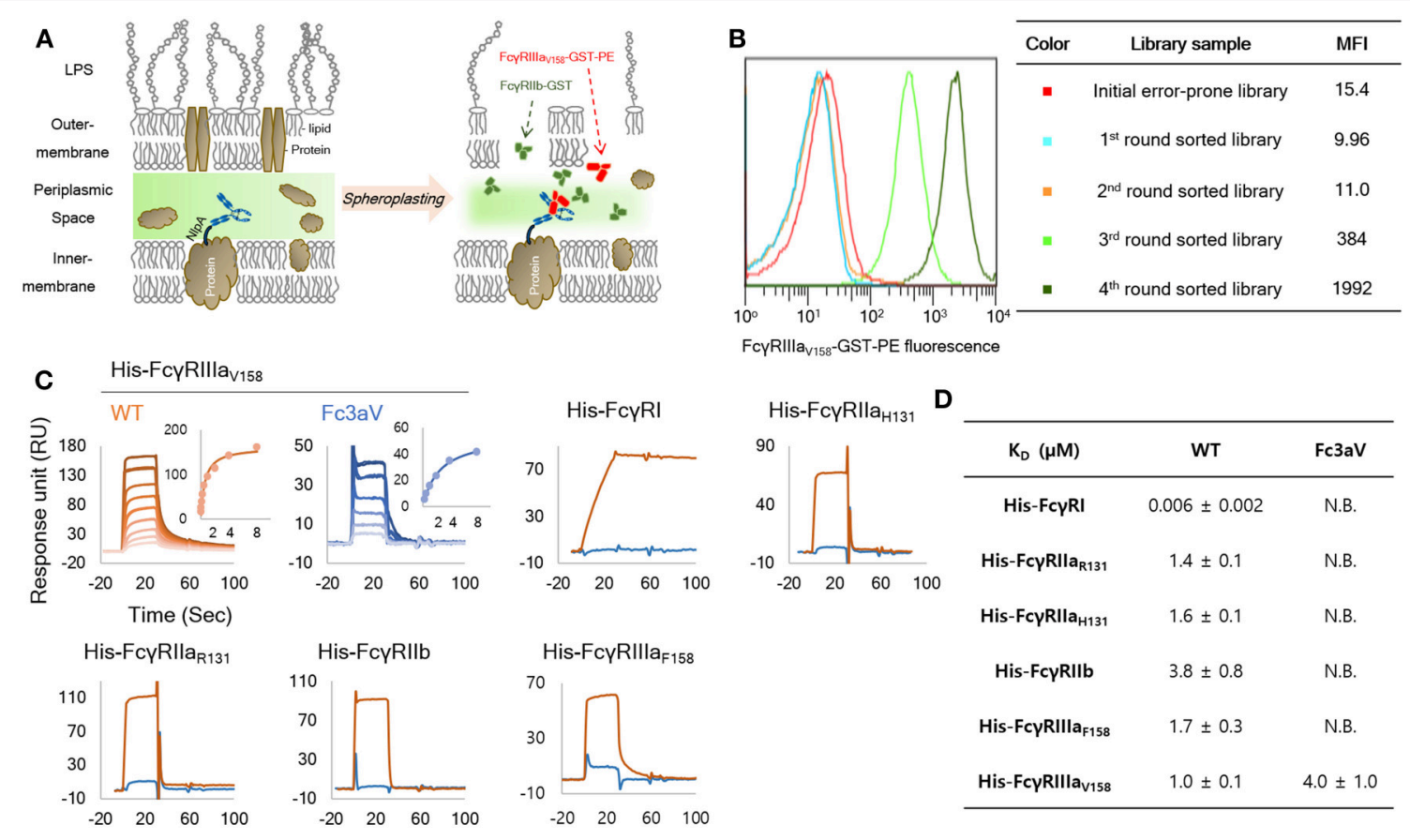

\begin{tabular}{|c|c|c|}
\hline $\mathrm{K}_{\mathrm{D}}(\mu \mathrm{M})$ & WT & $\mathrm{Fc} 3 \mathrm{aV}$ \\
\hline His-FcyRI & $0.006 \pm 0.002$ & N.B. \\
\hline His-FcyRIIa ${ }_{R 131}$ & $1.4 \pm 0.1$ & N.B. \\
\hline His-FcyRIIa ${ }_{H 131}$ & $1.6 \pm 0.1$ & N.B. \\
\hline His-FcyRIIb & $3.8 \pm 0.8$ & N.B. \\
\hline His-FcyRIIIa $\mathrm{F}_{\mathrm{F}} 58$ & $1.7 \pm 0.3$ & N.B. \\
\hline His-FcyRIIIa ${ }_{\mathrm{V} 158}$ & $1.0 \pm 0.1$ & $4.0 \pm 1.0$ \\
\hline
\end{tabular}

FIGURE 1 | Engineering and biochemical characterization of a of FcyRIllav158-specific, Fc domain variant: (A) Schematic diagram of the high throughput screening system used for the isolation of Fc $\gamma R$ Rlllav158_specific Fc variants from very large combinatorial libraries. Soluble fluorescent Fc $\gamma$ RIllav158-GST and a large excess of non-fluorescent Fc $\gamma$ RIIlb-GST as a competitor are used for cell labeling and FACS sorting. (B) MFI (median fluorescence intensity) of initial library (red, size: $1 \times 10^{9}$ ), and 1st (light blue), 2nd (orange), 3rd (light green), and 4th (green) round sorted populations. (C,D) SPR analysis of wild-type Trastuzumab (orange) and Trastuzumab-Fc3aV (sky blue) with monomeric His-tagged FcyRs. Surface plasmon resonance (SPR) sensorgrams (C) and equilibrium dissociation constants for of Fc3aV in $\mu \mathrm{M}$ (D). N.B. means RUmax of sensorgram is lower than $5 \mathrm{RU}$ with $8 \mu \mathrm{M}$ of each His-hFc $\gamma$ R. All experiments were repeated three times and error corresponds to standard deviation (s.d.).

A
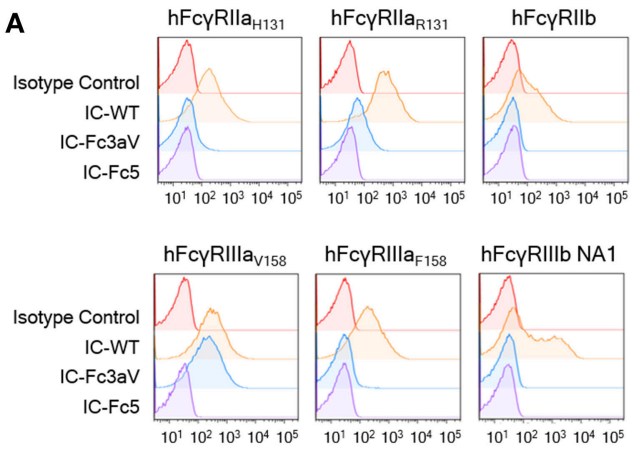

B
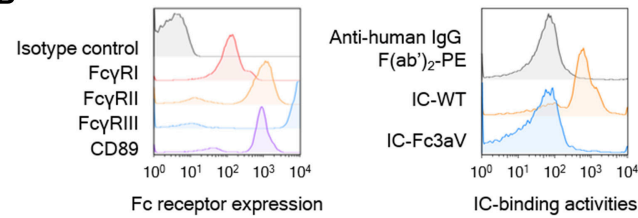

C

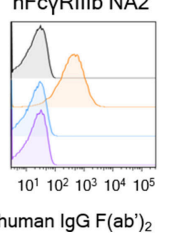

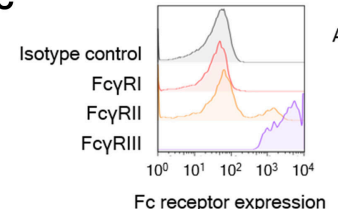

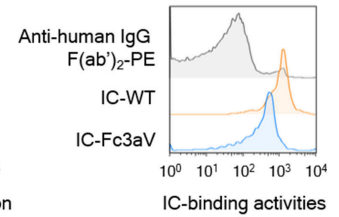

FIGURE 2 | Fc3aV binds to FcyRIIIIAV158 with exquisite selectivity (A) Binding activities of ICs (10 $\mu \mathrm{g} / \mathrm{mll}$ ), formed by mixing antibodies with F(ab') 2 anti-hlgG $\mathrm{F}\left(\mathrm{ab}^{\prime}\right)_{2}-\mathrm{PE}$, to human FcyRs expressed by transfectant $\mathrm{CHO}$ cell measured by FACS, when antibodies are: isotype control (red), wt Trastuzumab (orange), Trastuzumab-Fc3aV (sky blue), and Trastuzumab-Fc5 (purple). (B,C) Binding activities of ICs on human neutrophils (B) or NK cells (C); immune complexes were formed and used at the same concentration as in (A). Left panels: Expression level of FcyRs on neutrophils activated by IFN- $\gamma$ (B) or NK cells (C) detected by the respective anti-Fc $\gamma R$ antibodies conjugated to APC; Right panels: Binding of ICs formed by wt or Fc3aV Trastuzumab, onto neutrophils or NK cells, respectively. Representative data of three independent experiments are shown.

competitor (Figures 1A,B). Ninety-six individual clones from the 4th round of sorting were randomly picked and analyzed further. The 96 clones encoded 22 unique hFc variants in which S239T, V264E, V282M, T299A, L309Q, and A378V amino acid mutations were enriched (Figure S1). Interestingly, 16 out of 22 clones contained a T299A substitution in the C'E loop of $\mathrm{CH} 2$ domain. The T299A mutation disrupts the canonical $\mathrm{N}-\mathrm{X}-\mathrm{T} / \mathrm{S} \mathrm{N}$-linked glycosylation motif on the hFc and impairs, but not completely abolishes, hFc $\gamma \mathrm{R}$ binding [(24), Figure S3]. Bacteria displaying IgGs with three different mutant Fc domains, 
namely, TEMA (S239T, V264E, V282M, T299A), EAQ (V264E, T299A, L309Q), and Fc3aV (S239T, P248L, V264E, V282M, T299A, L309Q, A378V), were analyzed by FACS (Figure S2). Cells expressing TEMA, EAQ and Fc3aV Fc mutated IgGs showed 16-, 48.2-, and 62.4-fold increased binding activity for $h F c \gamma R I I I a_{V 158}-G S T$ dimers, respectively, compared with wild-type (wt) aglycosylated IgG1. In addition, TEMA and Fc3aV also slightly bound to hFc $\gamma$ RIIa or hFc $\gamma$ RIIb under these experimental conditions (Figure S2).

Several antibodies containing subsets of the amino acid substitutions found in TEMA, EAQ, and Fc3aV were expressed and analyzed in terms of their binding affinity and selectivity to purified monomeric, high-affinity hFc $\gamma$ RI-His or to GST-fused dimeric (and thus, higher avidity) versions of the low-affinity receptors, hFc $\gamma$ RIIa, hFc $\gamma$ RIIb, and hFc $\gamma$ RIIIa $(36,40)$. Three isolated Fc variants shared two mutations, V264E and T299A. First, the effect of $\mathrm{V} 264 \mathrm{E}$ on the $\mathrm{hFc} \gamma \mathrm{R}$-binding properties of aglycosylated Fc domain was investigated (Figure S3). Trastuzumab-V264E/T299A, showed higher hFc $\gamma$ RIIIa binding and decreased $h F c \gamma$ RIIb binding relative to the T299A variant (Figure S3). Similarly, Trastuzumab-EAQ (V264E, T299A, L309Q) showed higher affinity for hFc $\gamma$ RIIIa but lower hFc $\gamma$ RIIb binding relative to Trastuzumab-T299A/L309Q (Figure S3). Trastuzumab-Fc3aV showed selective binding to Fc $\gamma$ RIIIa $_{V 158}$ by ELISA, but still displayed some binding toward Fc $\gamma$ RIIIa 158 and Fc $\gamma$ RIIb (Figure S3).

Due to the low sensitivity achieved by direct ELISA, we opted to measure the $\mathrm{Fc}-\mathrm{Fc} \gamma \mathrm{R}$ interactions in a highly sensitive SPR experiment. Trastuzumab-Fc3aV showed specific binding to GST-fused dimeric hFc $\gamma$ RIIIa $_{\mathrm{V} 158}\left(K_{D}=0.2 \pm\right.$ $0.01 \mu \mathrm{M})$ without any significant binding to $400 \mathrm{nM}$ of GSTfused dimeric hFc $\gamma$ RIIa $131 / \mathrm{R} 131, \mathrm{hFc} \gamma \mathrm{RIIb}$, and hFc $\gamma \mathrm{RIIIa}_{\mathrm{F} 158}$ by SPR (Figure S4A and Table S1). The equilibrium dissociation constants for the binding of Trastuzumab-Fc3aV to monomeric hFc $\gamma$ Rs were also determined by SPR. Trastuzumab-Fc3aV exhibited no detectable response for any monomeric $h F c \gamma R$ except for $\mathrm{hFc} \gamma$ RIIIa $_{\mathrm{V} 158}$ to which it bound with a $K_{D}=4 \pm$ $1.0 \mu \mathrm{M}$ (Figures 1C,D and Figure S4B,C).

6The binding of ICs onto cells represents an exquisitely sensitive assay for detecting physiologically relevant IgG:Fc $\gamma \mathrm{R}$ interactions $(14,52)$. Large, high avidity ICs were formed by mixing $\mathrm{Fc} 3 \mathrm{aV}$ or other antibodies with goat $\mathrm{F}\left(\mathrm{ab}^{\prime}\right)_{2}$ anti-human $\mathrm{F}\left(\mathrm{ab}^{\prime}\right)_{2}$ and binding to $\mathrm{CHO}$ cells expressing the low affinity hFc $\gamma$ RIIa $_{\mathrm{R} 131}, \mathrm{hFc} \gamma \mathrm{RIIa}_{\mathrm{H} 131}, \mathrm{hFc} \gamma \mathrm{RIIb}, \mathrm{hFc} \gamma \mathrm{RIIIa}_{\mathrm{V} 158}$, and importantly hFc $\gamma$ RIIIaf 158 which only differs from hFc $\gamma$ RIIIa $_{V 158}$ by one amino acid or the hFc $\gamma$ RIIIb-NA1 or hFc $\gamma$ RIIIb-NA2 allotype which differs from hFc $\gamma$ RIIIa by 6-8 amino acids at high levels was evaluated by FACS. IC formed by Trastuzumab Fc3aV bound to hFc $\mathrm{RIIIav158}$ expressing $\mathrm{CHO}$ cells but did not show significant binding activities for all other hFc $\gamma$ Rs (Figure 2A). To examine whether ICs of Trastuzumab $\mathrm{Fc} 3 \mathrm{aV}$ bind to $\mathrm{hFc} \gamma \mathrm{RI}$-expressing cells in a physiologically relevant context we determined binding to neutrophils from human blood, which are activated with IFN $-\gamma$. As expected, ICs formed with Trastuzumab Fc3aV did not bind to activated neutrophils which express $h F c \gamma R I, h F c \gamma R I I a / b$, and hFc $\gamma$ RIIIb but not hFc $\gamma$ RIIIa (Figure 2B) (53).
hFc $\gamma$ RIIIa on the surface of NK cells has a different $N$-glycan composition relative to hFc $\gamma$ RIIIa on the surface of monocytes/macrophages or with hFc $\gamma$ RIIIa ectodomain produced recombinantly in Expi293F cells. Differences in receptor glycosylation can affect the affinity for IgG (54). Nonetheless, we found that, ICs formed with Trastuzumab Fc3aV show slightly lower binding to NK cells as those formed by wild-type antibodies, a finding entirely consistent with the lower affinity of Fc3aV determined by SPR (Figures 1D,2C).

\section{hFc $\gamma$ RIIla-Mediated Effector Functions in Various Effector Cells}

To determine how hFc $\gamma$ RIIIa contributes to immune effector functions, we performed ADCP and ADCC assays using antiCD20 Rituximab-Fc3aV or anti-Her2 Trastuzumab-Fc3aV and $\mathrm{CD}_{20}{ }^{+}$Raji cells or Her2 ${ }^{\text {high }}$ SK-BR-3 breast cancer cells as targets, respectively. As expected, Fc3aV-formatted antibodies with Trastuzumab or Rituximab Fab showed equivalent binding with their wt counterparts to $\mathrm{CD} 20^{+}$Raji cells or Her2 $2^{\text {high }}$ SK-BR-3 breast cancer cells, respectively since mutations of the Fc domain did not affect antigen binding (Figure S5). We first performed ADCP assays with gmM $\phi$, which had been differentiated in vitro from human peripheral bloodderived $\mathrm{CD}_{14}{ }^{+}$monocytes. gmM $\phi$ express $\mathrm{hFc} \gamma \mathrm{RI}$ at moderate, $\mathrm{hFc} \gamma \mathrm{RIIa} / \mathrm{b}$ at high and hFc $\gamma$ RIIIaviss $_{15}$ at low levels, as determined by flow cytometry (Figure 3A) (30-32, 35). Raji cells were labeled with fluorescent PKH67 and then opsonized with Fc-engineered Rituximab variants, followed by incubation with gmM $\phi$, as previously reported $(40,48)$. The extent of phagocytosis was evaluated using flow cytometry by determining the percentage of cells staining double positive for PKH67 and anti-CD14-APC or anti-CD11b-APC over the total number of $\mathrm{PKH}_{67}{ }^{+}$cancer cells. We found that Rituximab-Fc3aV, which as described above binds only to hFc $\gamma \mathrm{RIIIa}_{\mathrm{V} 158}$, has ADCP activity that is comparable to that of wt Rituximab (Figures 3B,C).

hFc $\gamma$ RIIIa-mediated phagocytosis by gmM $\phi$ was also confirmed with Her2 ${ }^{\text {high }}$ SK-BR-3 cancer cells opsonized with Trastuzumab-Fc3aV antibodies (Figures 3B,D). ADCP by either wt IgG- or Fc3aV- were significantly inhibited by the addition of a blocking, anti-CD16 $\mathrm{F}\left(\mathrm{ab}^{\prime}\right)_{2}[\mathrm{mAb}$ clone 3G8 (49-51)], confirming the importance of hFc $\gamma$ RIIIa in ADCP (Figures 3C,D). Opsonization of CD20 ${ }^{+}$Raji cells with Rituximab equipped with Fc5, an engineered hFc domain which as discussed above engages $\mathrm{hFc} \gamma \mathrm{RI}$ selectively, resulted in a low, but statistically significant level of ADCP. However, we did not detect phagocytosis of Her2 ${ }^{+}$SK-BR-3 cells using Trastuzumab-Fc5 (Figures 3C,D).

We also determined ADCC activity by detecting calcein$\mathrm{AM}$ release from cancer cells $\left(\mathrm{CD} 20^{+}\right.$Raji cells) with PBMC, monocytes, or NK cells, isolated from the same healthy donor ( $\mathrm{V} / \mathrm{V}$ or $\mathrm{V} / \mathrm{F}$ genotype), as effectors ( $n=3$ donors). Based on the weaker binding activity of immune complexes with Fc3aV antibodies on NK cells compared to that of w.t. IgG1 antibodies (Figure 2C), the ADCC potency of PBMCs, or NK cells using Rituximab-Fc3aV was weaker than the level observed with wt glycosylated IgG1 Rituximab (Figures 4A,B). Similarly, Rituximab-Fc3aV showed significant ADCC activity 
A

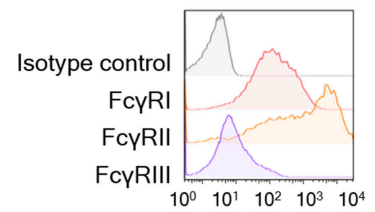

Fc receptor expression

B
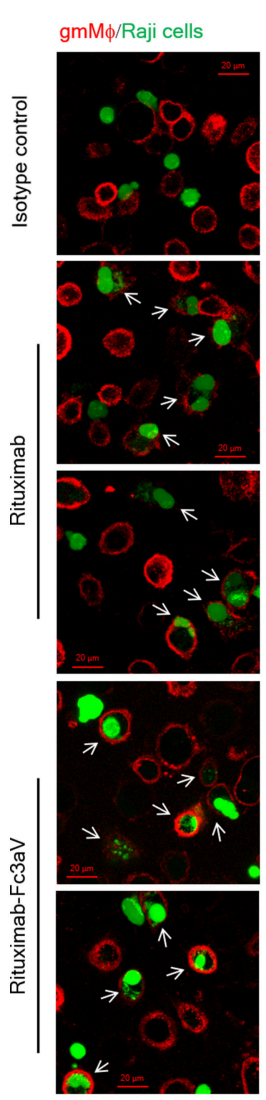

C

V/F genotype

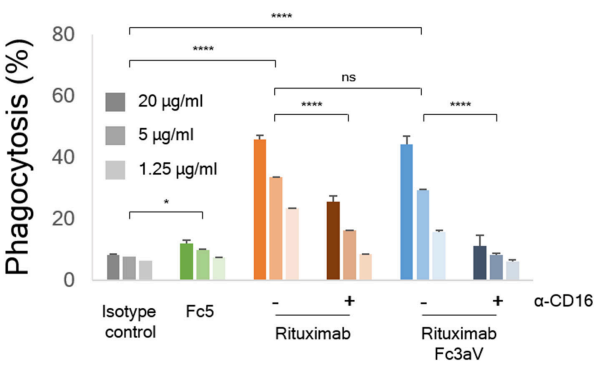

V/V genotype

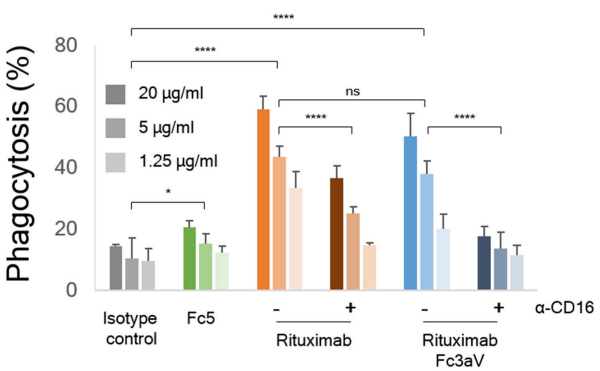

D V/F genotype

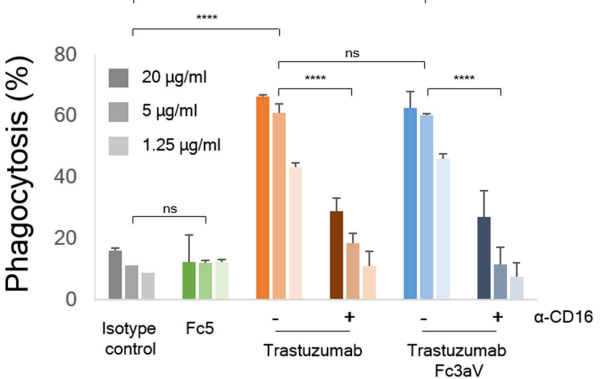

V/V genotype

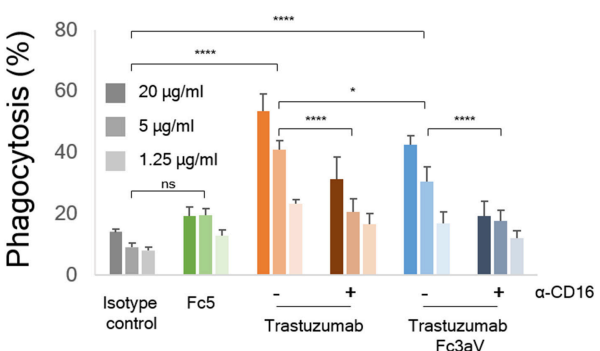

FIGURE 3 | In vitro phagocytosis assays. (A) Expression levels of Fc $\gamma R s$ on monocyte-derived human gmM $\phi$ were detected by FACS using the respective anti-Fc $\gamma R$ R-APC antibodies. (B) Fluorescent images of phagocytosis of cancer cells (green, left panel: Raji and right panel: SK-BR-3) by gmM $\phi$ (red). Macrophages were stained with anti-CD14 and anti-CD11b-APC and cancer cells were stained with Calcein-AM. White arrows indicate phagocytosed cancer cells. (C,D) ADCP assays with gmM $\phi$ (V/F and V/N genotypes) as effectors and (C) PKH67-labeled CD20+ Raji cells or (D) PKH67-labeled Her2high SK-BR-3 cells as targets (Effector:Target ratio of 10:1). Macrophages were pre-incubated with or without $10 \mu \mathrm{g} / \mathrm{ml}$ of anti-CD16 mAb $3 G 8 \mathrm{~F}\left(\mathrm{ab}^{\prime}\right)_{2}$ for 10 min prior to the addition of wt or variants of trastuzumab. ADCP data are shown for an FcyRllla heterozygous donor (V/F) and one donor homozygous for the FcyRlllav158 allotype (VN).

Representative data from for independent experiments. Error bars are standard deviations of triplicate samples. Statistical analysis was performed by two way ANOVA with Tukey's multiple comparisons test (ns: $P>0.05,{ }^{*} P \leq 0.05,{ }^{* \star} P \leq 0.01,{ }^{* \star *} P \leq 0.001,{ }^{* \star \star *} P \leq 0.0001$ ). 

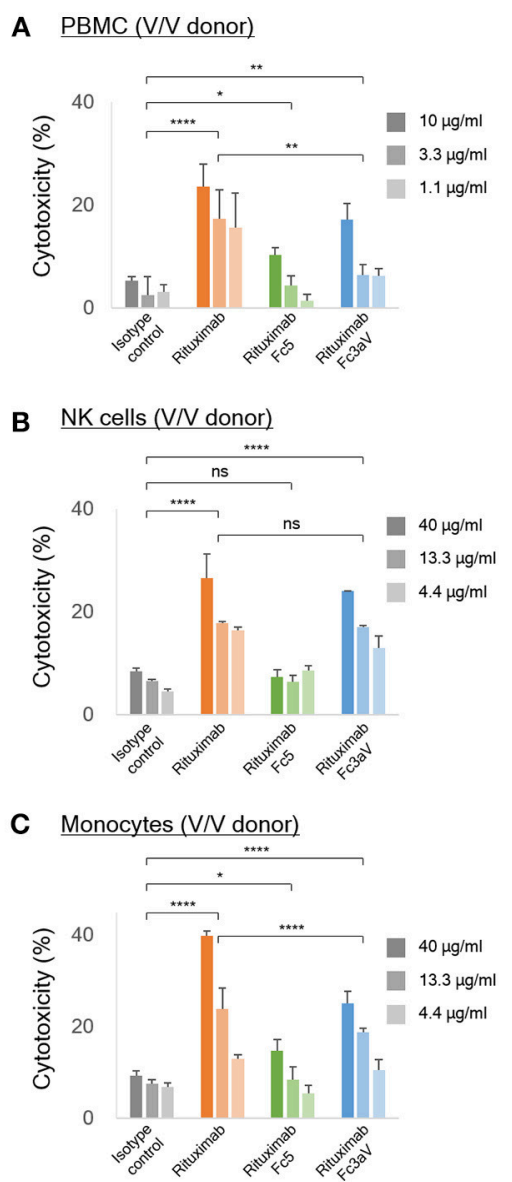

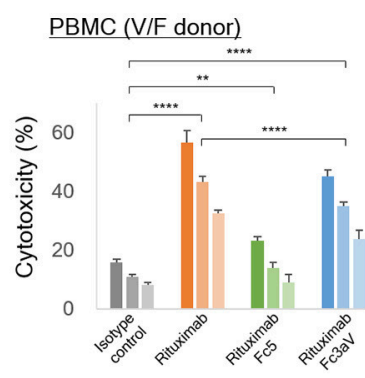

NK cells (V/F donor)

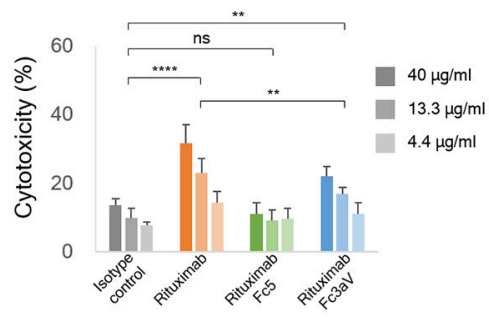

Monocytes (V/F donor)

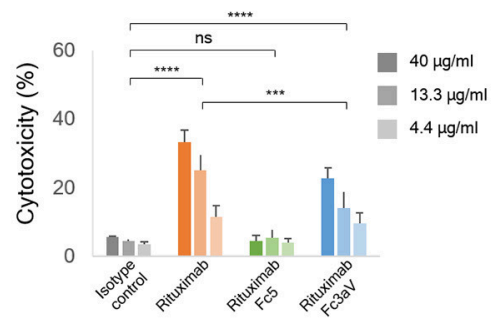

PBMC (V/F donor)

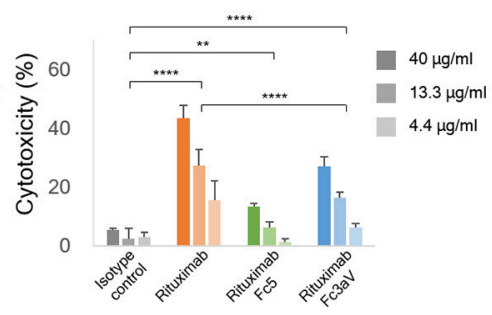

NK cells (V/F donor)

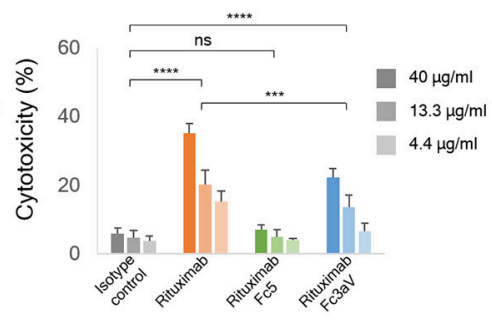

Monocytes (V/F donor)

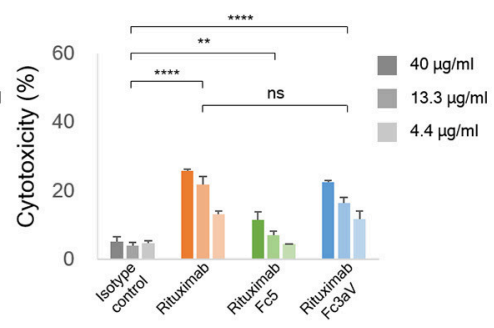

FIGURE 4 | In vitro ADCC assays. ADCC assays with calcein-AM loaded Raji cells as targets and (A) PBMCs, (B) NK cells, and (C) freshly isolated monocytes from the same healthy donor [homozygous VN (left) or heterozygous V/F (center and right) and E:T ratio = 10:1] as effector cells. (A-C) The level of the released calcein-AM was measured to detect target cell lysis after $4 \mathrm{~h}$. Error bars correspond to standard deviations of triplicate samples. Statistical analysis was performed by two way ANOVA with Tukey's multiple comparisons test (ns: $P>0.05,{ }^{\star} P \leq 0.05,{ }^{\star \star} P \leq 0.01,{ }^{\star \star \star} P \leq 0.001,{ }^{\star \star \star \star} P \leq 0.0001$ ).

with monocytes from one $\mathrm{V} / \mathrm{V}$ and two $\mathrm{V} / \mathrm{F}$ donors, which was weaker than w.t. Rituximab (Figure 4C). Consistent with our findings, recently Yeap et al. presented evidence that hFc $\gamma$ RIIIa (CD16a) ligation is important for ADCC by monocytes. We also examined whether antibodies formatted with the hFc $\gamma$ RIspecific Fc5 can trigger ADCC. Rituximab-Fc5 initiated a low but statistically significant activity of ADCC with PBMCs as effectors in all donors analyzed (Figure 4A). With monocytes we only observed a low level of hFc $\gamma$ RI mediated ADCC in two out of three donors, consistent with the high degree of hFc $\gamma \mathrm{RI}$ variability from donor to donor (Figure 4C). Finally, as expected, Fc5 formatted antibodies did not trigger ADCC with NK cells which do not express any hFc $\gamma$ RI (Figure 4B).

\section{DISCUSSION}

A number of engineered Fc domains including the SDIE (S239D/ I332E), SDALIE (S239D/ A330L/ I332E), S298A/ E333A/ K334A, GASDALIE (G236A/ S239D/ A330L/ I332E), and GASDIE (G236A/S239D/I332E) variants showing increased hFc $\gamma$ RIIIa affinity had been engineered $(5,55)$. However, all these Fcs show detectable and, in some instances, high affinity to other $\mathrm{hFc} \gamma \mathrm{R}$ and therefore they are not suitable for mechanistic studies to selectively delineate the phenotypes induced solely via the engagement of Fc $\gamma$ RIIIa. Removal of the single glycan in the IgG hFc domain markedly increases the flexibility of the $\mathrm{CH} 2$ conformation resulting in dramatically decreased binding to all $\mathrm{hFc} \gamma \mathrm{Rs}$ as well as to $\mathrm{C} 1 \mathrm{q}(44)$. We had shown earlier that mutations in aglycosylated human IgG Fc domains can stabilize a particular $\mathrm{CH} 2$ conformer and restore binding selectively either to a single $\mathrm{Fc}$ binding protein, e.g., hFc $\gamma \mathrm{RI}$ or $\mathrm{Clq}$ or, alternatively to multiple $\mathrm{hFc} \gamma \mathrm{Rs}(36,39,40)$. Extending these earlier studies, we have now engineered an aglycosylated hFc variant, Fc3aV, with high selectivity for hFc $\gamma$ RIIIav158 and containing seven amino acids substitutions (S239T, P248L, V264E, V282M, T299A, L309Q, and A378V). Antibodies with the $\mathrm{Fc} 3 \mathrm{aV}$ hFc domain do not show any binding to the high affinity receptor $h F c \gamma R I$ or to dimeric high avidity versions of the low affinity receptors $h F c \gamma R I I a / b$ by SPR. Consistent with this biophysical data, ICs formed by antibodies formatted 
with the Fc3aV domain did not bind significantly to $\mathrm{CHO}$ cells expressing low-affinity $h F c \gamma$ Rs except $h F c \gamma R I I I a v 158$. Since hFc $\gamma$ RIIIa glycoproteins expressed by HEK293 or CHO cells are exclusively modified by biantennary complex-type glycans with partial sialylation (56), and the $N$-glycan composition can in turn affect its affinity for $\operatorname{IgG}(54,57)$ we also evaluated binding activity of ICs to primary cells. Furthermore, immune complexes of Fc3aV antibodies bind to NK cells which express hFc $\gamma$ RIIIa and not to activated neutrophils which express $\mathrm{hFc} \gamma \mathrm{RI}, \mathrm{hFc} \gamma \mathrm{RIIa}$, and hFc $\gamma$ RIIIb but not hFc $\gamma$ RIIIa (Figures 2B,C).

We used Fc3aV to clarify the contribution of hFc $\gamma$ RIIIa to ADCP. Data from clinical studies and animal models have underscored the significance of phagocytosis in the clearance of cancer cells $(7,25-29,58)$. Importantly, the depletion of macrophages in mouse models was shown to abolish the therapeutic efficacy of anti-CD20, anti-CD30, or anti-CD40 antibodies in B-cell cancer models, in contrast to depletion of NK cells or neutrophils (26-29).

While earlier reports had suggested that ADCP is mediated primarily by binding to $\mathrm{hF} c \gamma \mathrm{RIIa}$ (37) here we present evidence showing that selective engagement of human hFc $\gamma$ RIIIa, is sufficient to trigger potent phagocytosis by gmM $\phi$. The ADCP activity we observed with $\mathrm{CD} 20^{+}$or $\mathrm{Her}^{+}$cancer cells as targets and gmM $\phi$ as effectors is particularly noteworthy because, as had been reported earlier and confirmed here, cell surface expression of $\mathrm{hFc} \gamma \mathrm{RIII}$ a on $\mathrm{gmM} \phi$ is significantly lower than that of hFc $\gamma$ RIIa and Fc $\gamma$ RI [Figure 3A,(36-38)]. One reason why selective ligation of $\mathrm{hFc} \gamma \mathrm{RIII}$ by $\mathrm{Fc} 3 \mathrm{aV}$ antibodies results in ADCP that is comparable to that observed with wt Rituximab which binds to all $h F c \gamma R$ on macrophages and notably the much more highly expressed hFc $\gamma$ RIIa is that, unlike wt antibodies Fc3aV does not bind to the inhibitory hFc $\gamma \mathrm{RIIb}$ and therefore is unable to trigger ITIM phosphorylation and downstream signaling processes. $\mathrm{hFc} \gamma \mathrm{RIIb}$ ligation is known to inhibit the effector functions initiated by the engagement of the activating Fc receptors including ADCP (2). We note that human macrophages show a large degree of phenotypic variations, which depend on the tissue of origin and on culture method in vitro and is associated with significant differences in Fc $\gamma$ R expression levels and especially hFc $\gamma$ RIIIa. For example, red pulp macrophages express significantly higher levels of Fc $\gamma$ RIIIa relative to the other Fc $\gamma$ Rs (31). Similarly in vitro differentiated macrophages stimulated with M-CSF have generally higher levels of hFc $\gamma$ RIIIa compared to $\operatorname{gmM} \phi(59,60)$. Moreover, donor to donor variation effects in ADCP assays are routinely observed. Along these lines, we note that the data in Figure 3D shows that with Trastuzumab-Fc3aV antibodies (but not when using Rituximab-Fc3aV and Raji cells as targets, Figure 3C), the absolute level of phagocytosis in an $\mathrm{hFc} \gamma \mathrm{RIII} \mathrm{V} / \mathrm{F}$ heterozygous donor was slightly higher than that observed in a different donor expressing the $\mathrm{V} / \mathrm{V}$ allele. The fact that high ADCP, at a level comparable to that observed with w.t. antibodies, could be mediated with the Fc3aV variant in four donors, with different target cells (Raji or SK-BR-3) and furthermore, that phagocytosis by $\mathrm{Fc} 3 \mathrm{aV}$ antibodies was inhibited by hFc $\gamma$ RIIIablocking antibodies support our conclusion that hFc $\gamma$ RIIIa engagement alone is sufficient to trigger significant ADCP by
gmM $\phi$.?NK cells which only express $\mathrm{hFc} \gamma \mathrm{RIIIa}$ and can release cytotoxic granules are considered to be the most important contributor to ADCC in vitro with PBMCs as effector cells (2). As expected, opsonization of tumor cells with Fc3aV antibodies triggered potent ADCC with both PBMCs and with NK cells as effectors. Similarly we found that the selective ligation of hFc $\gamma$ RIIIa on monocytes strongly triggers ADCC, a finding consistent with recent reports (10). As with the ADCP results discussed above, donor to donor variability precludes a comparison of subtle differences in the absolute magnitude of ADCC among donors. For example, in Figure 4, with PBMCs but not with monocytes or NK cells as effectors, the level of ADCC in a donor that is homozygous for the expression of the high affinity $158 \mathrm{~V}$ allele was lower than that of the V/F heterozygous donors. This may be in part due to the fact that the level of ADCC with PBMCs as effectors depends on factors other than the $\mathrm{hFc} \gamma \mathrm{RIII}$ allotype including, importantly, the ratio and phenotypes of monocytes to NK cells, since cytokines or receptors expressed by monocytes can impact NK cell-mediated cytotoxicity (61).

Somewhat unexpectedly we found that antibodies with the hFc $\gamma$ RI-selective Fc5 domain elicited much weaker ADCP with gmM $\phi$ opsonized with Fc3aV antibodies, even though as shown in Figure 3A FACS analysis shows a $>10$-fold lower signal for $\mathrm{hFc} \gamma \mathrm{RIII}$ on gmM $\phi$ s compared that for hFc $\gamma \mathrm{RI}$. However, it should be noted that the FACS data in Figure 3A does not reflect the absolute levels of the different receptors since the FACS data were obtained with different antibodies having different affinities for their respective $\mathrm{hF} c \gamma \mathrm{R}$ antigens. This effect is not due to poor activation of $\mathrm{hFc} \gamma \mathrm{RI}$ by Fc5 antibodies as we had established earlier that $\mathrm{Fc} 5$ antibodies are efficient in activating hFc $\gamma \mathrm{RI}$ and initiating target cell clearance by classical dendritic cells (39). The weaker effector functions associated with ligation of $\mathrm{hFc} \gamma \mathrm{RI}$ may be due to subtle, cell-specific effects related to differences in downstream signaling following ITAM phosphorylation and the elucidation of these effects will require further investigation.

In summary, functional studies with macrophages and other myeloid-derived cells capable of clearing opsonized targets using Fc3aV formatted antibodies may prove very useful for elucidating the role of $\mathrm{hFc} \gamma \mathrm{RIII}$ ligation on the importance of different effector functions and leukocytes subsets for the mechanism of action of therapeutic antibodies. Myeloid cells express multiple $\mathrm{hFc} \gamma \mathrm{Rs}$ and therefore when they are activated with immune complexes formed by numerous antibodies the resulting effector functions represent the integrated effect due to signaling by all the $\mathrm{hFc} \gamma \mathrm{Rs}$. The use of engineered $\mathrm{Fc}$ domains with absolute selectivity for only one $h F c \gamma R$ can be a powerful tool for elucidating the subtle signaling differences and phenotypic effects elicited by each individual Fc receptor and how these ultimately contribute to the clearance of target pathogenic cells.

\section{DATA AVAILABILITY}

All datasets generated for this study are included in the manuscript and/or the Supplementary Files. 


\section{AUTHOR CONTRIBUTIONS}

TK, C-HL, and GG conceived and designed the research. C-HL, TK, GD, JJ, OG, JL, JK, and WC performed the experiments. GG, C-HL, TK, GD, JJ, and PB analyzed the data. GG, C-HL, TK, GD, $\mathrm{JJ}$, JL, and PB wrote the paper.

\section{ACKNOWLEDGMENTS}

We thank Yuri Tanno for assistance with protein expression and Anna Webb for assistance with confocal

\section{REFERENCES}

1. Nimmerjahn F, Ravetch JV. Antibody-mediated modulation of immune responses. Immunol Rev. (2010) 236:265-75. doi: 10.1111/j.1600-065X.2010.00910.x

2. Nimmerjahn F, Ravetch JV. Fc $\gamma$ receptors as regulators of immune responses. Nat Rev Immunol. (2008) 8:34-47. doi: 10.1038/nri2206

3. Smith KGC, Clatworthy MR. Fc $\gamma$ RIIB in autoimmunity and infection: evolutionary and therapeutic implications. Nat Rev Immunol. (2010) 10:32843. doi: $10.1038 /$ nri2 262

4. Leibson PJ. The regulation of lymphocyte activation by inhibitory receptors. Curr Opin Immunol. (2004) 16:328-36. doi: 10.1016/j.coi.2004. 03.006

5. Bruhns P, Jönsson F. Mouse and human FcR effector functions. Immunol Rev. (2015) 268:25-51. doi: 10.1111/imr.12350.

6. Pincetic A, Bournazos S, DiLillo DJ, Maamary J, Wang TT, Dahan R, et al. Type I and type II Fc receptors regulate innate and adaptive immunity. Nat Immunol. (2014) 15:707-16. doi: 10.1038/ni.2939

7. Bakema JE, van Egmond M. Fc receptor-dependent mechanisms of monoclonal antibody therapy of cancer. In: Daeron M, Nimmerjahn F, editors. Fc Receptors Current Topics in Microbiology and Immunology. Springer International Publishing. (2014) 382:373-92. doi: 10.1007/978-3-319-07911-0_17

8. Hatjiharissi E, Xu L, Santos DD, Hunter ZR, Ciccarelli BT, Verselis $S$, et al. Increased natural killer cell expression of CD16, augmented binding and ADCC activity to rituximab among individuals expressing the Fc \{gamma\}RIIIa-158 V/V and V/F polymorphism. Blood. (2007) 110:2561-4. doi: 10.1182/blood-2007-01-070656

9. Ziegler-Heitbrock L. Blood monocytes and their subsets: established features and open questions. Front Immunol. (2015) 6:423. doi: 10.3389/fimmu.2015.00423

10. Yeap WH, Wong KL, Shimasaki N, Teo ECY, Quek JKS, Yong $\mathrm{HX}$, et al. CD16 is indispensable for antibody-dependent cellular cytotoxicity by human monocytes. Sci Rep. (2016) 6:34310. doi: 10.1038/ srep34310

11. Smyth MJ, Cretney E, Kelly JM, Westwood JA, Street SEA, Yagita H, et al. Activation of NK cell cytotoxicity. Mol Immunol. (2005) 42:501-10. doi: 10.1016/j.molimm.2004.07.034

12. Bruhns P. Properties of mouse and human $\operatorname{IgG}$ receptors and their contribution to disease models. Blood. (2012) 119:5640-9. doi: 10.1182/blood-2012-01-380121

13. Weiner GJ. Building better monoclonal antibody-based therapeutics. Nat Rev Cancer. (2015) 15:361-70. doi: 10.1038/nrc3930

14. Bruhns P, Iannascoli B, England P, Mancardi DA, Fernandez N, Jorieux $S$, et al. Specificity and affinity of human Fcy receptors and their polymorphic variants for human IgG subclasses. Blood. (2009) 113:3716-25. doi: 10.1182/blood-2008-09-179754

15. Weng W-K, Levy R. Two immunoglobulin G fragment C receptor polymorphisms independently predict response to rituximab in patients with follicular lymphoma. J Clin Oncol Off J Am Soc Clin Oncol. (2003) 21:3940-7. doi: $10.1200 / J C O .2003 .05 .013$ microscope. This work was supported by the Clayton Foundation (Austin, TX, USA), the Institut Pasteur and the Institut National de la Santé et de la Recherche Médicale (Paris, France).

\section{SUPPLEMENTARY MATERIAL}

The Supplementary Material for this article can be found online at: https://www.frontiersin.org/articles/10.3389/fimmu. 2019.00562/full\#supplementary-material
16. Liu D, Tian Y, Sun D, Sun H, Jin Y, Dong M. The FCGR3A polymorphism predicts the response to rituximab-based therapy in patients with nonHodgkin lymphoma: a meta-analysis. Ann Hematol. (2016) 95:1483-90. doi: $10.1007 /$ s00277-016-2723-x

17. Gavin PG, Song N, Kim SR, Lipchik C, Johnson NL, Bandos H, et al. Association of polymorphisms in FCGR2A and FCGR3A with degree of trastuzumab benefit in the adjuvant treatment of ERBB2/HER2-positive breast cancer: analysis of the NSABP B-31 trial. JAMA Oncol. (2017) 3:335-41. doi: 10.1001/jamaoncol.2016.4884

18. Umaña P, Jean-Mairet J, Moudry R, Amstutz H, Bailey JE. Engineered glycoforms of an antineuroblastoma IgG1 with optimized antibodydependent cellular cytotoxic activity. Nat Biotechnol. (1999) 17:176-80.

19. Lazar GA, Dang W, Karki S, Vafa O, Peng JS, Hyun L, et al. Engineered antibody Fc variants with enhanced effector function. Proc Natl Acad Sci USA. (2006) 103:4005-10. doi: 10.1073/pnas.0508123103

20. Liu Z, Gunasekaran K, Wang W, Razinkov V, Sekirov L, Leng E, et al. Asymmetrical $\mathrm{Fc}$ engineering greatly enhances antibody-dependent cellular cytotoxicity (ADCC) effector function and stability of the modified antibodies. J Biol Chem. (2014) 289:3571-90. doi: 10.1074/jbc.M113.513366

21. Niwa R, Satoh M. The current status and prospects of antibody engineering for therapeutic use: focus on glycoengineering technology. J Pharm Sci. (2015) 104:930-41. doi: 10.1002/jps.24316

22. Marcus R, Davies A, Ando K, Klapper W, Opat S, Owen C, et al. Obinutuzumab for the first-line treatment of follicular lymphoma. $N$ Engl J Med. (2017) 377:1331-44. doi: 10.1056/NEJMoa1614598

23. Capuano C, Pighi C, Molfetta R, Paolini R, Battella S, Palmieri G, et al. Obinutuzumab-mediated high-affinity ligation of Fc $\gamma$ RIIIA/CD16 primes NK cells for IFN $\gamma$ production. Oncoimmunology. (2017) 6:e1290037. doi: 10.1080/2162402X.2017.1290037

24. Dall'Ozzo S, Tartas S, Paintaud G, Cartron G, Colombat P, Bardos P, et al. Rituximab-dependent cytotoxicity by natural killer cells influence of FCGR3A polymorphism on the concentration-effect relationship. Cancer Res. (2004) 64:4664-9. doi: 10.1158/0008-5472.CAN-03-2862

25. Gül N, Babes L, Siegmund K, Korthouwer R, Bögels M, Braster R, et al. Macrophages eliminate circulating tumor cells after monoclonal antibody therapy. J Clin Invest. (2014) 124:812-23. doi: 10.1172/JCI66776

26. Oflazoglu E, Stone IJ, Gordon KA, Grewal IS, van Rooijen N, Law C-L, et al Macrophages contribute to the antitumor activity of the anti-CD30 antibody SGN-30. Blood. (2007) 110:4370-2. doi: 10.1182/blood-2007-06-097014

27. Oflazoglu E, Stone IJ, Brown L, Gordon KA, van Rooijen N, Jonas M, et al. Macrophages and Fc-receptor interactions contribute to the antitumour activities of the anti-CD40 antibody SGN-40. Br J Cancer. (2009) 100:113-7. doi: 10.1038/sj.bjc.6604812

28. Horikawa M, Minard-Colin V, Matsushita T, Tedder TF. Regulatory B cell production of IL-10 inhibits lymphoma depletion during CD20 immunotherapy in mice. J Clin Invest. (2011) 121:4268-80. doi: 10.1172/JCI59266

29. Minard-Colin V, Xiu Y, Poe JC, Horikawa M, Magro CM, Hamaguchi Y et al. Lymphoma depletion during CD20 immunotherapy in mice is mediated by macrophage FcgammaRI, FcgammaRIII, and FcgammaRIV. Blood. (2008) 112:1205-13. doi: 10.1182/blood-2008-01-135160 
30. Dahal LN, Dou L, Hussain K, Liu R, Earley A, Cox KL, et al. STING activation reverses lymphoma-mediated resistance to antibody immunotherapy. Cancer Res. (2017) 77:3619-31. doi: 10.1158/0008-5472. CAN-16-2784

31. Nagelkerke SQ, Bruggeman CW, den Haan JMM, Mul EPJ, van den Berg TK, van Bruggen $\mathrm{R}$, et al. Red pulp macrophages in the human spleen are a distinct cell population with a unique expression of $\mathrm{Fc}-\gamma$ receptors. Blood Adv. (2018) 2:941-53. doi: 10.1182/bloodadvances.2017015008

32. Martinez FO, Sica A, Mantovani A, Locati M. Macrophage activation and polarization. Front Biosci J Virtual Libr. (2008) 13:453-61. doi: 10.274 $1 / 2692$

33. Golay J, Da Roit F, Bologna L, Ferrara C, Leusen JH, Rambaldi A, et al. Glycoengineered CD20 antibody obinutuzumab activates neutrophils and mediates phagocytosis through CD16B more efficiently than rituximab. Blood. (2013) 122:3482-91. doi: 10.1182/blood-2013-05-504043

34. Herter S, Birk MC, Klein C, Gerdes C, Umana P, Bacac M. Glycoengineering of therapeutic antibodies enhances monocyte/macrophage-mediated phagocytosis and cytotoxicity. J Immunol. (2014) 192:2252-60. doi: 10.4049/jimmunol.1301249

35. Guilliams M, Bruhns P, Saeys Y, Hammad H, Lambrecht BN. The function of $\mathrm{Fc} \gamma$ receptors in dendritic cells and macrophages. Nat Rev Immunol. (2014) 14:94-108. doi: 10.1038/nri3582

36. Jung ST, Kelton W, Kang TH, Ng DTW, Andersen JT, Sandlie I, et al. Effective phagocytosis of low Her2 tumor cell lines with engineered, aglycosylated IgG displaying high Fc $\gamma$ RIIa affinity and selectivity. ACS Chem Biol. (2012) 8:368-75. doi: 10.1021/cb300455f

37. Richards JO, Karki S, Lazar GA, Chen H, Dang W, Desjarlais JR. Optimization of antibody binding to FcgammaRIIa enhances macrophage phagocytosis of tumor cells. Mol Cancer Ther. (2008) 7:2517-27. doi: 10.1158/1535-7163.MCT-08-0201

38. Ruffell B, Au A, Rugo HS, Esserman LJ, Hwang ES, Coussens LM. Leukocyte composition of human breast cancer. Proc Natl Acad Sci USA. (2012) 109:2796-801. doi: 10.1073/pnas.1104303108

39. Jung ST, Reddy ST, Kang TH, Borrok MJ, Sandlie I, Tucker PW, et al. Aglycosylated IgG variants expressed in bacteria that selectively bind Fc $\gamma \mathrm{RI}$ potentiate tumor cell killing by monocyte-dendritic cells. Proc Natl Acad Sci USA. (2010) 107:604-9. doi: 10.1073/pnas.0908590107

40. Lee C-H, Romain G, Yan W, Watanabe M, Charab W, Todorova B, et al. IgG Fc domains that bind $\mathrm{C} 1 \mathrm{q}$ but not effector $\mathrm{Fc} \gamma$ receptors delineate the importance of complement-mediated effector functions. Nat Immunol. (2017) 18:889-98. doi: $10.1038 /$ ni. 3770

41. Jefferis R. Recombinant antibody therapeutics: the impact of glycosylation on mechanisms of action. Trends Pharmacol Sci. (2009) 30:356-62. doi: 10.1016/j.tips.2009.04.007

42. Sazinsky SL, Ott RG, Silver NW, Tidor B, Ravetch JV, Wittrup KD. Aglycosylated immunoglobulin G1 variants productively engage activating Fc receptors. Proc Natl Acad Sci USA. (2008) 105:20167-72. doi: 10.1073/pnas.0809257105

43. Simmons LC, Reilly D, Klimowski L, Raju TS, Meng G, Sims P, et al. Expression of full-length immunoglobulins in Escherichia coli: rapid and efficient production of aglycosylated antibodies. J Immunol Methods. (2002) 263:133-47. doi: 10.1016/S0022-1759(02)00036-4

44. Borrok MJ, Jung ST, Kang TH, Monzingo AF, Georgiou G. Revisiting the role of glycosylation in the structure of human IgG Fc. ACS Chem Biol. (2012) 7:1596-602. doi: 10.1021/cb300130k

45. Mancardi DA, Iannascoli B, Hoos S, England P, Daëron M, Bruhns P. FcgammaRIV is a mouse IgE receptor that resembles macrophage FcepsilonRI in humans and promotes IgE-induced lung inflammation. J Clin Invest. (2008) 118:3738-50. doi: 10.1172/JCI36452

46. Erbe AK, Wang W, Gallenberger M, Hank JA, Sondel PM. Genotyping single nucleotide polymorphisms (SNPs) and copy number variability (CNV) of the FCGRs (FCGR3A and FCGR2C) expressed on NK cells. Methods Mol Biol Clifton NJ. (2016) 1441:43-56. doi: 10.1007/978-1-4939-3684-7_4
47. Dobosy JR, Rose SD, Beltz KR, Rupp SM, Powers KM, Behlke MA, et al. RNase H-dependent PCR (rhPCR): improved specificity and single nucleotide polymorphism detection using blocked cleavable primers. BMC Biotechnol. (2011) 11:80. doi: 10.1186/1472-6750-11-80

48. Kelton W, Mehta N, Charab W, Lee J, Lee C, Kojima T, et al. IgGA: a "cross-isotype" engineered human Fc antibody domain that displays both IgG-like and IgA-like effector functions. Chem Biol. (2014) 21:1603-9. doi: 10.1016/j.chembiol.2014.10.017

49. Laborde EA, Vanzulli S, Beigier-Bompadre M, Isturiz MA, Ruggiero RA, Fourcade MG, et al. Immune complexes inhibit differentiation, maturation, and function of human monocyte-derived dendritic cells. J Immunol. (2007) 179:673-81. doi: 10.4049/jimmunol.179.1.673

50. Choi EI, Wang R, Peterson L, Letvin NL, Reimann KA. Use of an anti-CD16 antibody for in vivo depletion of natural killer cells in rhesus macaques. Immunology. (2008) 124:215-22. doi: 10.1111/j.1365-2567.2007.02757.x

51. Tamm A, Schmidt RE. The binding epitopes of human CD16 (Fc gamma RIII) monoclonal antibodies. Implications for ligand binding. J Immunol. (1996) 157:1576-81.

52. Lux A, Yu X, Scanlan CN, Nimmerjahn F. Impact of immune complex size and glycosylation on IgG binding to human Fc $\gamma$ Rs. J Immunol. (2013) 190:4315-23. doi: 10.4049/jimmunol.1200501

53. Gillis C, Gouel-Chéron A, Jönsson F, Bruhns P. Contribution of human Fc $\gamma$ Rs to disease with evidence from human polymorphisms and transgenic animal studies. Front Immunol. (2014) 5:254. doi: 10.3389/fimmu.2014.00254

54. Patel KR, Roberts JT, Subedi GP, Barb AW. Restricted processing of CD16a/Fc $\gamma$ receptor IIIa N-glycans from primary human NK cells impacts structure and function. J Biol Chem. (2018) 293:3477-89. doi: 10.1074/jbc.RA117.001207

55. Wang $\mathrm{X}$, Mathieu $\mathrm{M}$, Brezski RJ. IgG Fc engineering to modulate antibody effector functions. Protein Cell. (2018) 9:63-73. doi: $10.1007 / \mathrm{s} 13238-017-0473-8$

56. Zeck A, Pohlentz G, Schlothauer T, Peter-Katalinić J, Regula JT. Cell typespecific and site directed $\mathrm{N}$-glycosylation pattern of Fc $\gamma$ RIIIa. J Proteome Res. (2011) 10:3031-9. doi: 10.1021/pr1012653

57. Hayes JM, Frostell A, Karlsson R, Müller S, Martín SM, Pauers M, et al Identification of $\mathrm{Fc}$ gamma receptor glycoforms that produce differential binding kinetics for rituximab. Mol Cell Proteomics. (2017) 16:1770-88. doi: 10.1074/mcp.M117.066944

58. Clynes RA, Towers TL, Presta LG, Ravetch JV. Inhibitory Fc receptors modulate in vivo cytoxicity against tumor targets. Nat Med. (2000) 6:443-6. doi: $10.1038 / 74704$

59. Santegoets KCM, Wenink MH, van den Berg WB, Radstake TRDJ. Fc gamma receptor IIb on GM-CSF macrophages controls immune complex mediated inhibition of inflammatory signals. PLoS ONE. (2014) 9:e110966. doi: 10.1371/journal.pone.0110966

60. Nagelkerke SQ, Dekkers G, Kustiawan I, van de Bovenkamp FS, Geissler J, Plomp R, et al. Inhibition of Fc $\gamma$ R-mediated phagocytosis by IVIg is independent of IgG-Fc sialylation and Fc $\gamma$ RIIb in human macrophages. Blood. (2014) 124:3709-18. doi: 10.1182/blood-2014-05-576835

61. Trembath AP, Markiewicz MA. More than decoration: roles for natural killer group 2 member D ligand expression by immune cells. Front Immunol. (2018) 9:231. doi: 10.3389/fimmu.2018.00231

Conflict of Interest Statement: The authors declare that the research was conducted in the absence of any commercial or financial relationships that could be construed as a potential conflict of interest.

Copyright $\odot 2019$ Kang, Lee, Delidakis, Jung, Richard-Le Goff, Lee, Kim, Charab, Bruhns and Georgiou. This is an open-access article distributed under the terms of the Creative Commons Attribution License (CC BY). The use, distribution or reproduction in other forums is permitted, provided the original author(s) and the copyright owner(s) are credited and that the original publication in this journal is cited, in accordance with accepted academic practice. No use, distribution or reproduction is permitted which does not comply with these terms. 